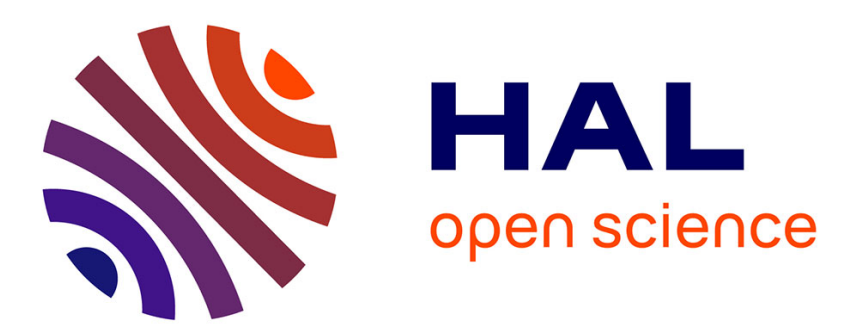

\title{
Corporate governance and the governance of knowledge: rethinking the relationship in terms of corporate coherence
}

Jackie Krafft, Jacques-Laurent Ravix

\section{- To cite this version:}

Jackie Krafft, Jacques-Laurent Ravix. Corporate governance and the governance of knowledge: rethinking the relationship in terms of corporate coherence. Economics of Innovation and New Technology, 2008, 17 (1-2), pp.79-96. hal-00203550

\section{HAL Id: hal-00203550 \\ https://hal.science/hal-00203550}

Submitted on 15 Jan 2008

HAL is a multi-disciplinary open access archive for the deposit and dissemination of scientific research documents, whether they are published or not. The documents may come from teaching and research institutions in France or abroad, or from public or private research centers.
L'archive ouverte pluridisciplinaire HAL, est destinée au dépôt et à la diffusion de documents scientifiques de niveau recherche, publiés ou non, émanant des établissements d'enseignement et de recherche français ou étrangers, des laboratoires publics ou privés. 


\title{
"Corporate Governance and the Governance of Knowledge: Rethinking the Relationship in Terms of Corporate Coherence"
}

\author{
Jackie Krafft and Jacques-Laurent Ravix \\ CNRS-GREDEG, 250 rue Albert Einstein, 06560 Valbonne, France \\ Tel: 0493954170 / 42 32; Fax: 04936537 98; \\ E-mail: Jackie.Krafft@idefi.cnrs.fr; ravix@idefi.cnrs.fr
}

\begin{abstract}
:
Corporate governance and the governance of knowledge were for a long time distinct fields of analysis. Reasons for this incompatibility are linked to the restricted vision of corporate governance supported by shareholder value which essentially refers to information rather than knowledge. In this paper, we argue that other visions of corporate governance exist which are also closer to knowledge dynamics and knowledge governance problems. We elaborate thus on the possible reconciliation between corporate governance and the governance of knowledge. We sustain that each actor (the manager and the investor) embodies a piece of diversified and localised knowledge related to his/her specific domain and field of experience, and these different modules of knowledge have to be recombined by an appropriate mode of corporate governance that stimulates corporate development. In this perspective, the reconciliation really appears essential since managers, by defining and selecting innovative processes, and investors, by determining the money that is invested to sustain these processes, both take part to the creation and governance of new knowledge by the firm. We show that this reconciliation can be based on the notion of corporate coherence of the cognitive firm that allows replacing the conventional conflicting vision of corporate governance by a new vision based on cooperation between managers and investors that collectively contribute to corporate development and coherence.
\end{abstract}

Key words:

Corporate governance, corporate coherence, corporate finance, corporate development, governance of knowledge, knowledge dynamics.

JEL Classification:

G 30, G 31, G 32, O 30, O 31, O 32 


\section{Introduction}

The purpose of this paper is to investigate the relationship between corporate governance and the governance of knowledge. On the one hand, corporate governance refers to the general system by which firms are owned and managed. On the other hand, the governance of knowledge is concerned with how actors (i.e., individuals and organisations) can generate new knowledge in specific domains and fields where they have accumulated sufficient levels of competences and experience. We argue that though often considered as distinct bodies of analysis in the recent literature, these issues are nevertheless closely related. Moreover, we advocate that this relationship is crucial to the understanding of how corporate finance and corporate development interact. We also argue that managerial as well as financial control have a decisive role on corporate coherence, by determining how the money is invested to sustain the coherent development of the productive resources of the firm.

Today, complex relationships between investors and managers are essentially analysed as an optimal contracting problem. This optimal contract provides a realignment of incentives of the manager in the interest of shareholders and investors, and precludes any discretionary behaviour from the manager's side (Schleifer and Vishny, 1997; Zingales, 1998). This conventional vision of corporate governance, often called the shareholder value vision, leaves very little space to the governance of knowledge. Firstly, because knowledge is here assimilated to the manager's private information on the evolution of demand, the competitive context, the profitability of the company, that the investor induces him to reveal by offering stock options, organizing boards of directors, and favouring hostile takeovers, etc. Secondly, because there is a dominant belief that new knowledge and competences can generally be acquired externally rather than created internally. The outcome is thus a very limited vision of the governance of knowledge-intensive companies involved in changing environment (Krafft and Ravix, 2005).

The governance of knowledge appears also today as an established body of analysis. Basic assumptions are that (a) knowledge is in itself localised, specialised and dispersed, and (b) the process of knowledge generation, coordination and diffusion is implemented step by step, through the contribution of various actors, and with irreversible effects from one period to the other. Knowledge dynamics is at the core of this body of analysis. It is concerned with the identification of each modules of knowledge that could potentially be created, as well as key actors holding these bits of knowledge. It is also concerned with the way in which these different modules of knowledge should be reassembled, as well as on the way in which the different actors need to be organized in order to participate in the creation of new knowledge in a complementary manner (Antonelli, 2003). Within the last fifteen years, some contributions have focused on key actors of the governance of knowledge inside the firm. The cooperative theory of the firm (Aoki, 1984), and the stakeholder vision of corporate governance (Blair, 1995) are among the early contributions. Other emerging approaches centred on human capital and intangible assets, and on the role of entrepreneurs as coordinators of human capital and knowledge resources also develop in order to elaborate an understanding of the nature of corporate knowledge (Rajan and Zingales, 1998).

In this paper, we argue that the best way to relate corporate governance and the governance of knowledge is to refer to a cognitive vision of the firm. This cognitive vision is mostly concerned with firms' knowledge and competence rather than products or markets. The modern multiproduct divisionalized corporation is thus defined as a nexus of different kinds 
of knowledge and competence articulated through different capabilities and learning processes. In these companies, we sustain that the key issue is the one identified by agency theory, i.e. the relationship between investors and managers. But contrary to the shareholder value vision where corporate governance is based on agency problems and market evaluation criteria, corporate governance here means that investors and managers interact and collaborate in a process of constructing the cognitive coherence of the firm ${ }^{1}$. The firm is cognitively coherent in that its knowledge, competence, as well as organizational and learning processes tend together to create an efficient process of corporate development, i.e. a process that provides an effective coordination of interrelated resources and activities.

The outline of the paper is the following. Section 2 analyses the content and results of the approaches that attempt to reconcile corporate governance and the governance of knowledge. In view of these developments, Section 3 shows that the key issue lies in the construction of corporate coherence referring to a cognitive vision of the modern multiproduct divisionalized corporation. This allows to investigate an appropriate vision of the complementary functions of managers and investors in the construction of corporate knowledge. Section 4 thus follows with implications on the governance of cognitive firms, based on the idea that each actor (here, the manager and the investor) embodies a piece of diversified and localised knowledge related to their respective domains and fields of experience. Corporate governance lies in the coherent and sequential coordination of these modules of knowledge to ensure corporate development. Section 5 concludes.

\section{Corporate governance and the governance of knowledge: an emerging reconciliation}

Corporate governance and the governance of knowledge were for a long time markedly distinct fields of analysis. In what follows, we analyse the reasons of this incompatibility which is in fact largely based on the distinction between knowledge and information, and their respective abilities to be transferred and appropriated. We also underline that the opposition between corporate governance and the governance of knowledge essentially holds when corporate governance is driven by the maximisation of shareholder value that diffuses the idea that perfect information can be restored in any situation, provided the price for perfect information is paid. However, some contributions in the literature also sustain that there are other visions of corporate governance, based on human capital and the entrepreneurial behaviour of the manager, which are closer to knowledge dynamics and knowledge governance problems. These advances - especially the most recent ones - transformed the initial incompatibility between corporate governance and the governance of knowledge into a closer connection.

\footnotetext{
${ }^{1}$ Of course, corporate governance is concerned with a large category of actors, and rules and principles of corporate governance may differ from one country to another. The institutional context matters (financial and labour market rules, education system, etc.). But here we focus on the manager-investor relationship, and substitute the conflicting vision by a cooperative vision, precisely to criticize agency theory that tends to impose the conflicting aspect of this relationship as a central problem in a universal vision of corporate governance.
} 


\subsection{The initial incompatibility}

The field of the governance of knowledge emerged largely in critical reaction to the dominance of conventional approaches that used to assimilate innovation to problems of creation and diffusion of information. Knowledge dynamics approaches advocate that knowledge is more than information, in that while information is global, codified and easily transferred, knowledge is localised, specialised and dispersed (Antonelli, 2003, 2001; Witt, 2003; Pavitt, 2001; Metcalfe, 1995; Freeman, 1995; Nelson, 1994; Lundvall, 1992). This implies that, as far as the coordination of knowledge is concerned, the point is to determine where and how different bits of knowledge that enter in the innovation process are created, and how the innovation process is proceeded by the interaction of each knowledge holder, and not simply by the appropriation or the purchase of their specific knowledge. Knowledge dynamics is also based on the argument that different bits of knowledge, each originated in local and specific environments, are not substitutable. Rather, within this approach, bits of knowledge are intrinsically complementary. This implies for instance that it will not be possible for a company to integrate the knowledge developed by another company if the adequate absorptive capacities (for example, an internal $\mathrm{R} \& \mathrm{D}$ activity in qualitative and quantitative coherence with external $R \& D$ ) were not put in place prior to the M\&A or alliance of the two companies (Cohen and Levinthal, 1990).

This mode of coordination and vision of innovation is largely different from the one recommended in corporate governance, especially as soon as it is oriented towards the maximisation of shareholder value, a principle that emerged in the 1980s. In that case, it is sustained that all information asymmetries among agents (mainly shareholders and managers) have to be eliminated, that a contractual structure of organization has to be generalized within the firm in order to limit conflicts and restore efficiency, and that the introduction of financial indicators in the management of this contractual structure of information is certainly the best solution to increase the performance of the company (Schleifer and Vishny, 1997). Also, the acquisition of external $R \& D$ is generally considered as the best solution to create value in a short period of time. In that case, the lack of internal R\&D can be corrected, and thus simply substituted, by the external R\&D of an acquired company. Shareholders and financial analysts will often support this type of strategy, and this will increase the value of the firm in stock markets (Brown, Dittmar and Servaes, 2005; Gompers and Lerner, 1990).

We have thus two polar, largely opposed ways of thinking the governance of innovative firms. One is centred on the idea that innovation emerges from attempts to render compatible heterogeneous agents and the large spectrum of what they have accumulated, combined and generated in terms of knowledge. The other is that efficiency in performance is obtained by a drastic realignment of incentives and informational structures of the different conflicting actors, with an increasing reference to the creation of value in financial terms

This major incompatibility between corporate governance and the governance of knowledge is not irreversible, however. Indeed, corporate governance cannot be reduced to the maximisation of shareholder value. Basically corporate governance is about the way in which firms are owned and managed and, at the core of this problem, is the relation between investors and managers. Nothing can prevent to think that investors and managers also collaborate to the governance of knowledge and ultimately contribute, in a complementary way, to the creation of knowledge in the firm. This idea tends to be supported in the following set of converging views. 


\subsection{Converging views towards reconciliation}

These attempts have a common feature. They all integrate human capital as a structural element of the firm, as far as important as financial capital, and specify the role of each of the developers of this composite capital: the entrepreneur and the employees for human capital, shareholders and bankers for financial capital. These approaches largely differ in their respective analytical background, but they all have a common goal, which is to consider the firm as a collective process of knowledge creation.

\subsubsection{The insider corporate governance vision}

One of the arguments that have structured the early literature supporting the need of reconciliation is that, from the observation of different national systems of corporate enterprise, external and conflicting control by shareholders is not a unique model. In many countries, (Japan, Germany, France), internal control by the different partners that are involved in the development of the firm also exists. In this so-called tradition of insider corporate governance, the definition and selection of collective learning processes are not reduced to investors or managers, but widely shared amongst the different stakeholders.

In the case of Japan, Aoki (1984) argues that diverging interests between partners do not prevent the elaboration of positive interactions and common objectives. He proposes on this basis a cooperative theory of the firm in which the different parties are all engaged in a bargaining game. Managers play a central role in this game, since they are in charge of the maximisation and distribution of the "relational quasi-rent", which corresponds to the surplus generated by the cooperation of partners.

The cooperative theory of the Japanese firm advances that the accumulation of specific financial and human resources that produce the quasi-rent is only possible if (an only if) a mutual engagement of the holders of these resources takes place: investors should gain a sufficient rate of return for their investments, employees should evolve in their revenues and careers, while managers coordinate the bargaining game. In the meantime, the last financial crisis demonstrated the inadequacy of the Japanese model. The traditional private and specific evaluation based on bilateral relations between a bank and a company that supports the Japanese banking system model appears to outperform significantly in a financial market system where the evaluation is public and diffused to a large community of competing investors. More generally, this system also seems to be more adapted to a situation of predictable demand, and regular technical progress (Aglietta and Rébérioux, 2005).

\subsubsection{The stakeholder vision}

In the 1990s, a new way of thinking attempted to reconcile the different actors of the firm and thus abandon the exclusive reference to conflicting corporate governance. This reconciliation underlines that these actors are involved in a collective process central to corporate development. Corporate finance is dedicated to the way in which the allocation of returns (within the firm, and beyond the boundaries of the firm to include partners such as suppliers, clients, investors, etc.) has to be oriented in order to favour the development of resources and thus to stimulate economic performance.

On the one hand, contributions in the domain of political sciences or management theory emerged (Kelly et al., 1997; Mitchell et al., 1997; Donaldson and Preston, 1995; Freeman, 
1984), stressing that since the firm in a broad sense is composed of various actors all contributing to the economic performance and value of the firm, then they should be involved and rewarded adequately.

On the other hand, economic contributions also appear, such as Blair (1995) who is often considered as one of the pioneers in the development of an economic theory of the stakeholder perspective. The argument here is that investors and shareholders do invest in the productive assets of the enterprise and thus take a risk since the investment can be a success but also a failure. For this, they are quite naturally 'residual claimants' in the process. But, apart from this financial commitment, other forms of investments co-exist and also contribute to the economic performance with a risk associated. One of the key forms of investment is human capital and thus, employees of the company that invest in their own human capital can also be considered as residual claimants.

This stakeholder vision involves going a step forward. The development of the firm is necessarily a collective process. Corporate finance has to take this crucial element into account and ensure the conditions of this development through the adequate reward of the different stakeholders that invest in the (productive, but especially human) capital of the firm.

\subsubsection{Human capital and critical resource theory}

In the late 1990s, the preceding propositions are complemented by a new approach, the critical resource theory, developed by Rajan and Zingales (1998), and Zingales (2000). This approach especially applies to knowledge intensive companies where the entrepreneur plays a central role in knowledge creation. The point of departure of the analysis is that the nature of the firm is changing. The concept of ownership has traditionally been perceived by transaction costs economics (Williamson, 1985) and the new theory of property rights (Grossman and Hart, 1986) as the ownership of physical assets and, consequently, power, authority and residual claims were all based on this vision of ownership. Today, however, firms are also composed of a range of other resources as creative knowledge, ideas and unique skills, professional control, corporate reputation, that sometimes generate a higher value than physical assets. The concepts of ownership and control have thus to be redefined to include these changes concerning the firm.

In this modern firm, the entrepreneur has a critical resource due to his specific skills, talents and ideas, which are the most important source of potential value creation for the firm. However, though the entrepreneur controls the access to this critical resource (no one within the company can have exactly the same skills, talents, and ideas), the effective value created by the firm is ultimately dependent on how the entrepreneur develops complementarities between his own specific resource and the resources of each of his collaborators. By the development of adequate complementarities, the role of the entrepreneur is thus to ensure the accumulation of specific investment in critical resources for the firm, leading to a vision of the firm as "the web of specific investments built around a critical resource" (Zingales, 2000, p. 1645).

In that case, though corporate control lies in the entrepreneur's hands, i.e. in his ability to develop the critical resource of the firm, corporate finance is linked to the complementarities relationships that were developed among collaborators within the firm. For this reason, the entrepreneur also has to reward his collaborators in respect with their investment in the firm, i.e. in their investment to the development of the critical resource. 
With this contribution, which is both based on an analytical model and supported by empirical evidence, the view that the firm is a collective entity that has to be developed by the interaction of complementary actors coordinated by the entrepreneur is reaffirmed. Moreover, important implications for a renewal in corporate governance are suggested, based on the fact that the usual distinction between ownership and control is not necessarily operational in a context where the entrepreneur and its collaborators become the direct and sole owners of the critical resource supporting the value of the new firm. Since technological, regulatory, and institutional innovations have made finance more widely available, the access to capital market is easier for entrepreneurs, and this changes significantly the nature of power relationships among shareholders and managers.

\subsubsection{Empire building versus entrepreneurial learning}

Another important dimension of corporate governance is what could be called "external" corporate governance. This points out the way in which corporate governance activity is shaped by different restructuring and acquisition activities such as takeovers, leveraged buyouts and mergers, witnessed during periods of greater dominance of capital markets. For instance, it has been shown that the pattern of corporate governance activities in the United States was dominated by hostile takeovers and leveraged buyouts in the 1980s, whereas the 1990s saw a substantial decrease of hostile takeovers, mergers being articulated with shareholder value principles implying a better cooperation of boards of directors and shareholders (Holmström and Kaplan, 2001; Andrade, Mitchell and Stafford, 2001).

The traditional agency theory explanation of mergers and takeovers relies on the search for some way to discipline managers and lead them to behave in accordance with shareholders' goals rather than pursuing their own interest. Takeovers are defined as critical corporate governance mechanisms in Britain and the United States used to control managerial discretion (Jensen, 1993). For instance, hostile takeovers are targeting not only poorly managed companies, but also those incumbent managers who engaged their company in adventurous and autocratic "empire building" activities. Another mechanism for disciplining managers is the market for corporate control by which mergers are supposed to facilitate the transfer of corporate control to a new management team trying to outperform the previous one.

The empire building view is challenged by research on corporate management and business strategies putting forward cognitive aspects of M\&As. These studies address the question of external corporate governance exerted through mergers and acquisitions and suggest different interpretations of restructuring activities. Referring to the Austrian literature on entrepreneurship, uncertainty and economic calculation, and relying on an empirical study of corporate divestitures, Klein and Klein (2002) propose an entrepreneurial market process view on corporate governance. The empire building view presumes that the acquisitions made by a manager in search of power and prestige are inefficient from the outset, leading to subsequent divestitures or spin-offs. In the market process perspective, poor long-term performance does not indicate systematically ex ante inefficiency. A divestiture of previously acquired assets may mean that entrepreneurs are engaged in a learning process and "experiment" new profit opportunities, by acquiring new information after the merger has taken place. Using evidence on mergers in the US telecommunications industry, Ellig (2002) shows that knowledge issues are also part of the managers' motivation for mergers.

Following the similar analytical vein, resource-based theories of strategic management and dynamic transaction costs approaches refer to knowledge issues to analyse the organization of 
industry through the influence of business institutions. The main argument in this literature is that mergers are used to facilitate the creation and recombination of capabilities (Langlois and Robertson, 1995; Teece, Pisano and Shuen, 1997).

\subsubsection{Summing up}

These developments have thus tended to show that shareholder value is not appropriate to modern, knowledge-intensive firms for the following reasons. Firstly, physical assets can easily be replaced and are thus not unique to corporate development; on the contrary, human assets are crucial elements in the firm's survival and development. Secondly, in the meantime, the value of human capital is increasing, and this leads individual workers with a greater independence towards the firm and a higher possibility to go and work elsewhere; financing in capital market is also easier for these individuals and eventually enables them to run their own company. Thirdly, external corporate governance by M\&As, takeovers, etc. lead to a rationalization of the structure of the industry that goes beyond the treatment of agency problems focusing on ownership-control distinction and managerial discretion. Corporate finance and corporate development are two faces of the same problem, that of maintaining the coherence of productive processes.

The question of corporate coherence emerges as the crucial question for corporate governance in a modern economy. The investor and the manager have to organise and finance the coordination of knowledge within collective learning processes in order to maintain the cognitive coherence of corporate development.

\section{Cognitive Aspects of Corporate Coherence}

The linking of corporate governance and the governance of knowledge calls for a cognitive approach to the firm to which Penrose (1959) gave the first path-breaking insights. Penrose defines the multi-business firm as a collection of productive resources, the growth of which is mainly obtained through a diversification process coherently shaped by managers' knowledge and control over disposable sets of resources and competencies. The problem of corporate coherence is at the centre of a specific literature that goes from the analysis of firm growth and corporate diversification to the study of the cognitive aspect of corporate coherence. These developments are a crucial step towards new foundations of corporate governance.

\subsection{Diversification, coherence and economic performance}

The empirical literature on diversification and performance of the multiproduct divisionalized firm that developed in the 1970s and 1980s essentially addressed the question of whether related diversification is better performing than unrelated diversification. Rumelt (1974) first answered positively to the question whereas other subsequent studies were less affirmative (see the survey of Ramanujam and Varadarajan, 1989). The main problem with this literature is that authors measure relatedness only at the industry or market level, rather than exploring the ability of the firm to create and exploit synergies of various types. This criticism gave birth to new analytical developments concerning both the domains of economic and strategy research. 
In the 1990s, the resource-based view of the firm inspired by Penrose's contribution insisted on the role of firms' specific resources and capabilities in shaping corporate diversification and coherence (Chatterjee and Wernerfelt, 1991). The essential idea is that firms grow from their existing potential for growth, i.e. along trajectories shaped by the exploitation of their existing resources and competences and the role of managerial resources. Following the same tradition, a subsequent research program, the competence-based theory of the firm, elaborates on capabilities and human assets as cognitive categories internally constructed through learning processes and experimentation (Foss, 1993; Teece et al., 1994).

Thus, coherence becomes a cognitive concept incorporating elements such as organizational learning within the firm, path-dependency characteristics, the depth and scope of technological opportunities in the neighbourhood of the firm's own technology and R\&D activities, and the influence of the selection environment. Today, the notion of coherence tends to get an operational content in the empirical field with the development of indicators of relatedness, proximity, similarity, and interconnectedness. The main critic to the competencebased literature is that it essentially focuses on configurations of resources and competencies at a given point in time (Foss and Christensen, 2001; Piscitello, 2004). Thus there is a need to interpret corporate coherence in a more dynamic way.

\subsection{A process approach to corporate coherence}

In their theoretical essay, Foss and Christensen (2001) use insights from the economic literature on market processes (Austrian theory of the entrepreneur and the market process, evolutionary economics, post-Marshallian theory of institutions) in order to address the dynamic notion of corporate coherence. The authors first elaborate on Hayek's notion of the division of knowledge among agents, and the fact that knowledge dispersal among separate individuals possessing only bits of incomplete, sometimes contradictory and tacit knowledge needs to be integrated through an institutional 'order', namely the market price system. The analysis of this market coordination has been developed with the concept of market process in which the entrepreneur plays a stabilizing role through the entrepreneur's alertness to arbitrage (Kirzner, 1973), or a more disruptive role due to his participation to a Schumpeterian process of creative destruction (Lachmann, 1989). There is thus a first problem concerning knowledge, that of the coordination of knowledge dispersal. On the market, this problem is handled by the price system and entrepreneurs' alertness. But in modern multiproduct divisionalized corporation, this problem also exists and its solution relies on corporate entrepreneurs, management information systems, corporate routines and corporate cultures.

A second knowledge problem exists, the one of knowledge creation, i.e. how new knowledge is created and exploited. This problem is treated by a set of converging theories: evolutionary economics with the notion of routines (Nelson and Winter, 1982) introducing pathdependency and inflexibility but also specialization and coherence; behaviouralist organisation theories identifying the trade-off between exploration and exploitation of new knowledge (March, 1991); and post-Marshallian economics defining the trade-off between differentiation (exploration) and integration (exploitation) (Loasby, 1991). These approaches simultaneously address both knowledge problems.

As Foss and Christensen argue, "Knowledge Problem 1", i.e. knowledge dispersion, is not simply highlighted by monitoring efforts and aligning incentives as in the modern theory of 
organization. The process approach to corporate coherence allows firms to solve the coordination of knowledge dispersal "by various means, such as command, management information systems, routines and shared cognitive constructs" (Foss and Christensen, 2001, p. 222). Concerning "Knowledge Problem 2", i.e. knowledge creation, encompassing the creation of new knowledge and the creation of new variety, "new knowledge arises from Schumpeterian 'new combinations', that is, from the discovery of complementarities between relevant stocks of knowledge and localized learning processes" (ibid.).

Relating to the above reflections and following also a Coasean-Richardsonian tradition for which the nature of the firm is mainly to coordinate production processes defined as intertemporal arrangements of closely complementary activities and related competences (Coase, 1972; Richardson, 1972; Langlois and Robertson, 1995), there appears an image of the role of managerial hierarchies in generating corporate coherence. Large modern firms are mainly considered as structures of complementary knowledge assets involved in collective learning processes. Managerial control is useful in such firm, as far as it is considered as an entrepreneurial activity of creating diversity with new assets and competences in a new business as well as exploring new experimentations in existing business.

This vision of corporate entrepreneurship calls for another interpretation of the relationship among shareholders and managers that goes beyond the traditional distinction between ownership and control. The respective roles of managers and investors participating in the collective learning process of the cognitive firm, and the way they attain or preserve corporate coherence of the modern multi-product divisionalized firm, become new issues in the process of firms' valuation and corporate governance.

\section{Valuation and governance of the cognitive firm}

Managers and financiers are mostly intertwined in the process of solving corporate coherence problems in the modern cognitive firm. Each actor is endowed with a different piece of knowledge that has to be recombined in a process of collective learning oriented towards corporate development. It is now widely recognized that, in most advanced economies, production requires not only such traditional factors as capital and labor but also skills, organizational structures and processes, culture, and other factors collectively referred to as "intangible assets" (Jorgenson, 1995; Hall, 1993; Griliches, 1980; Lev and Sougiannis, 1996; Bresnahan, Brynjolfsson, and Hitt, 2000, 2002). In this new context, physical assets ownership is less central, and we stress that the role of the investor is mainly to develop the skills necessary to evaluate the firm as a cognitive entity. Knowledge appears as a crucial element in the valuation of companies that generates financial movements and interactions with industrial dynamics. Indeed, investors have to develop new competences and experience in the evaluation of companies, since usual market criteria refer to tangible assets and require long term track record that are not applicable nor available in knowledge-intensive companies. In that perspective, the valuation of intangibles by investors becomes a real issue: valuation is the outcome of a process of coordination of different elements of knowledge related to the perceived ability of entrepreneurs to create new technological and market opportunities; valuation is also a key element in sustaining some entrepreneurial projects (and not others) that are part of the evolution of the industry. This current focus on the evaluation of the cognitive coherence of the firm renders questionable the usual separation between ownership and control. If knowledge is a key element, the real determinant of the co-evolution between 
financial dynamics and industrial dynamics lies in how knowledge is coordinated among investors and managers, and in the way in which these actors arrive or not at cognitive coherence of the firm by corporate governance. In that perspective, we show that a cooperative interaction between investors and managers is more desirable than a conflicting one, mainly because both the manager and the investor are involved in the process of coordination and creation of new knowledge. We call this an "extended corporate entrepreneurship". We argue that this cooperative interaction is not spontaneous and that learning procedures are still to be implemented among managers and investors to generate the extended corporate entrepreneurship.

\subsection{The valuation of companies' knowledge}

The new phenomenon that has emerged over the last decade is that intangible assets became a key information in the valuation of firms by investors. As a consequence, there has been an increasing divergence between recent stock market valuation of firms based on intangible assets and older one based on tangible assets. The measure and understanding of this divergence have been already analysed and documented in the literature. One of the key issues is whether this change in the reference variable is due to purely rational determinants or more evolutionary forces of change. The debate on these issues leads to two visions of the investor in evaluating the modern cognitive firm. Though different and largely opposed, these visions support the idea that financial dynamics shapes and is shaped by industrial dynamics, especially within periods of radical change where new knowledge is created and old competences are destroyed.

\subsubsection{The rational vision}

Hall (2001a), on the basis of the value of equity claims on nonfarm, nonfinancial corporations as a ratio to GDP and over the period 1947-2000, argues that swings of the stock market are due to rational behaviours of economic agents valuing intangibles on the basis of the expected growth of their cash flows, and not (as this usually holds) the value of debt claims or the value of the plant and equipment owned by corporations. This effect especially applies during the period of the development of the new economy in which, for instance, the market value of Internet companies was high because investors expected increasing profits in the future, based on the valuation of their intangibles ${ }^{2}$. In this approach, cash flow growth based on changes in the value of intangibles is selected as the key rational factor in understanding movements in the stock market (see also Hall, 2000, 2001b; Brynjolfsson, Hitt, Yang, 2002).

\subsubsection{The evolutionary vision}

The divergence between financial and industrial capital valuation can find an alternative explanation in more evolutionary approaches, such as Perez (2002) and Freeman and Louca (2001), with the long wave hypothesis. In this perspective, a technological system emerges, grows, develops and matures and, within each stage of development, are created the determinants that will drive to the inexorable decline of the system. Then, over the long run, but regularly, the system auto-corrects its own characteristics and the major trends in which it was engaged. This means that when deviations between market and physical values of capital

\footnotetext{
${ }^{2}$ In early 2000 , Yahoo! had a market value of $\$ 140$ billion with only $\$ 158$ million of physical capital and still maintained a market value of $\$ 37$ billion, after the financial crash (Hall, 2000).
} 
become too important, such as the ones observed just before the 1929 and 2000 crashes of the stock market, then there is a selection mechanism of companies that drives to the exit of the ones with the largest deviations. In this scenario, companies such as the dotcoms in 2000 with overvalued intangible assets compared to physical capital were deemed to exit the market. This explanation is highly deterministic, however. The life cycle metaphor, with large downswings regulating at the same time the industry and the stock market, does not explain how corporate finance shapes the process of corporate development.

\subsubsection{Cognitive processes of creative destruction}

Another evolutionary explanation shows that there is a co-evolution of growth rate instability and stock price volatility that is closely related to the creative destruction described by Schumpeter (Mazzucato, 2002, 2003; Mazzucato and Semler, 1999). Contributions use evidence on the early stages of development of industries, one related to the old economy the automobile industry - and the other related to the new economy - the computer industry. It is shown that the decades in which relative growth rates and stock prices were the most volatile were the same decades in which innovation was the most radical and with new competences created and older ones destroyed. As a matter of fact, when incumbents loose their dominant position in the face of new entry, this tends to leave the place for new knowledge and competences to be created that are generally highly valued by the stock market. Volatility (and more largely movements in the stock market) captures and also shapes the process of creation and destruction of knowledge that is inherent to the evolution of industries.

From what precedes, we can see that knowledge and intangibles are now a key part in the evaluation of companies by investors. In the modern financial market system, this evaluation is generally largely communicated and public among the community of investors. In that perspective, when the entrepreneurial manager engages a new project, he has to do more than simply attract investors. He has to elaborate with them the conditions that will sustain the coherent development of the company.

\subsection{The governance of cognitive coherence}

The governance of cognitive firms emerges from the attempt to solve two types of knowledge problems defined in Section 3: knowledge dispersion and knowledge creation. Modern multiproduct divisionalized companies develop collective learning processes that are essentially dedicated to jointly solve these problems. A conflicting mode of corporate governance between investors and managers is made at the expense of such collective processes, and may drive to major shifts and ruptures in the evolution of cognitive firms. We provide firstly evidence that shows that corporate governance based on the opposition between investors and managers leads to major coordination problems and turbulences in a large range of industries, but especially in highly innovative industries. Thus, this drives knowledge-intensive companies to develop new forms of collaboration between investors and managers that tend to replace this traditional opposition between ownership and control. Secondly, we advocate that managers and investors have to implement a collective corporate entrepreneurship dedicated to solving both the coordination of knowledge dispersal and the creation of new knowledge. 


\subsubsection{Consequences of conflicting governance}

Parallel to the literature about diversification and coherence in the domain of industry studies (see Section 3), empirical evidence in the valuation of stocks stresses that corporate diversification usually generates negative value on stock markets, while corporate coherence creates positive value (Denis, Denis and Sarin, 1997; Servaes, 1996; Comment and Jarrella, 1995; Lang and Stulz, 1994). This evidence is highly related to the unsuccessful conglomerate merger wave that occurred in the 1970 and early 1980s. This evidence is also strongly based on the long-lived consensual idea, developed by Jensen (1986) according to which managers with larger debt capacity and free cash flow generated by diversification tend to undertake non value maximising strategies. This leads us back to the empire building issue according to which, as reported above, hostile takeovers are useful for disciplining managers and forcing them to behave in the interest of shareholders and financiers. This argument is strongly based on a non-cooperative vision of the firm in which the problem is to solve agency conflicts between investors and managers. However, this conflicting vision does not apply systematically. Recent studies over the period 1993-1998 on corporate scope strategies of large US firms listed on NYSE, AMEX and NASDAQ show that diversification is not necessarily performance discounting, thus contradicting the empire building argument that imposing the view of the investor improves efficiency (Singh, Mathur and Gleason, 2004, Anderson, Bates, Bizjak, and Lemmon, 2000).

In fact, these recent contributions show that firms change their scope strategies (either diversifying or refocusing) primarily on the basis of managerial perceptions. The perceptions can be supported or not by facts and thus generate good or bad outcomes but, in the case of poor performing diversified firms, these studies show that the free cash flow argument does not apply. Large differences in management and ownership structure between diversified and coherent firms are essentially attributable to the different stages of corporate evolution and not to the fight against discretionary behaviours from the manager. As the firm ages, the board becomes naturally larger, and tends to be composed of a larger share of outsiders and a minor share of insiders. As a consequence, agency conflict does not provide a valid explanation of cross-sectional differences in corporate scale and scope, and related performance. Rather, the alternative proposition is that corporate governance, as well as economic performance, changes with the life cycle of the company. In particular, poorly performing firms, irrespective of their prior degree of diversification and adoption of diversifying or focusing strategies, can potentially generate gains with properly executed strategies. Management and ownership structures evolve with the performance impact of diversification and focus strategies.

In a non-cooperative context, managers and investors each evolve along their own specific cognitive frames. This situation generates unpredictable results in the concrete world, such as sudden displacement of financial investments from the company to its direct competitor, inadequate amounts of money invested in the development of productive resources, corporate scope strategies implemented in order to increase the domain of activities of the firm and its economic performance that tend ex post to be contested by investors and shareholders. Empirical evidence shows that these phenomena concern all companies. Large companies are just as vulnerable to the decisions of a small number of investors as small or midsize companies are. There is thus a high correlation between the net change in the collective holdings of investors and changes in the company's stock price (Coyne and Witter, 2002). 
The inadequacy of conflicting corporate governance is particularly strong in innovative activities and knowledge-intensive industries as this is argued by a number of recent studies. Lazonick and O'Sullivan (2002) show that the mode of corporate governance by shareholder value introduced in innovative firms has generally accelerated the process of financial crash that occurred in 2000, and introduced high turbulence in firms' demography and dramatic changes in market shares. Fransman (2002) shows that this phenomenon led to a paroxysm in the info-communications industry, and that shareholder value proved to be an important part of the telecoms boom and bust. Finally, it can be shown that maximizing shareholder value in corporate governance greatly favoured the financing of emerging firms via the stock markets and the acquisition of new knowledge and competences on the basis of mergers and acquisitions over the pre-financial crash period. In the meantime, it also greatly affected the viability of these companies in the post-crash period, and finally resulted in overinvestment, excess capacity, downsizing and a sharp fall in the share price, revenue, and profitability of both the telecoms operators and their equipment suppliers (Krafft and Ravix, 2005).

\subsubsection{Coordination through corporate entrepreneurship}

The positive aspect of cooperative action linking investors and managers can be documented. In Cisco's case (Carpenter et al., 2003; Chesborough, 2003; Mayer and Kenney, 2004; Krafft and Ravix, 2005), managers were key actors in the innovation process, since they could choose by themselves the strategies and modes of organization. Decision makers were essentially three men (Valentine as the main venture capitalist, Morgridge and Chambers as to executives) who acted as entrepreneurs and not as owners. They were distinct from the initial founders of the company and always persuaded shareholders and investors to accept the managerial strategy oriented towards a development of competences based on the engagement of complementary investments using M\&As as well as internal development in an innovative breakthrough. This attitude resulted in the fact that Cisco outperformed its competitors in the early 2000s. From this case, the cooperation among managers and investors can be characterized as an "extended corporate entrepreneurship" based upon a collective learning process of creation of diversity and exploration of novelty.

In a cognitive firm, the key role of strategic management is appropriately adapting, integrating and reconfiguring internal and external organisational skills, resources and functional competencies toward changing environment. Managers regularly develop specific production plans which are mainly based on local, private and tacit knowledge. The source of the competitive advantage of the firm stems from dynamic capabilities rooted in high performance routines operating inside the firm, embedded in the firm's process and conditioned by its history. This innovative behaviour takes place in a rivalry context where other firms behave by imitation and replication in order to preserve their particular sets of competencies (Malerba and Orsenigo, 1996; Dosi and Malerba, 2002; Teece and Pisano, 1994). On the market side, the investor also tends to behave according to cognitive patterns rather than according to the efficient market hypothesis defined by Fama (1970). Most of the time, stock prices do not correspond to fundamental values because, even if investors are striving to do the correct thing, however they have restricted capacities and specific modes of behaviour that shape their investment decisions. Investors are intrinsically heterogenous (Grenadier and Weiss, 1997), they proceed according to a cognitive model with trial and errors (Valliere and Peterson, 2004), and they refer only to some basic indicators while neglecting others (Wheale and Amin, 2003). 
The notion of extended corporate entrepreneurship means that managers and investors are largely involved in corporate development and coherence. Their respective contributions, based on their specific domains and fields of experience, take place in a sequential timing ${ }^{3}$.

The manager intervenes first, since his role is to innovate and organise ex ante the planning of production. His specific domain and field of experience are twofold. First, as a Schumpeterian innovator, he explores new business opportunities, new products, creates diversity, and promotes innovative activities. Second, as a Chandlerian professional manager, he maintains the viability of the firm by providing continuity in the process of innovation engaged by the firm and by limiting strategies from competitors in order to preserve the market position of the firm. The investor intervenes subsequently, and his role is not to limit the discretionary power of the manager, but rather to support and finance the entrepreneurial activity. As a financier, his basic task lies in investing the money and in controlling ex post the outcomes of the productive choices implemented by the manager. Beside the usual function of performance measurement, investing in knowledge intensive firms also means to develop a set of competences that support corporate coherence and corporate development. These competences of the investor include assistance with acquisitions and help in facilitating strategic partnership by providing the manager with financial and non financial information about the companies potentially involved in future M\&As and cooperations, contributions to the design of employees compensation plans, and participation to reporting activities.

Finally, it is important to note that this process of collaborative interaction is neither evident nor easy to obtain. In fact, if collaboration is expected and desirable, still corporate entrepreneurship may fail: the transfer and use of knowledge is difficult and costly, especially because of knowledge characteristics such as cumulability, fungeability and stickiness (Antonelli, 2006). Moreover, strategic management contributions report that, quite amazingly, whereas most of the companies tend to systematically discover and understand the complex behaviour of their customers, suppliers, partners, or employees, they are very much ignorant on the basic characteristics and behaviours of their key investors. Studies also report that investors can routinely misinterpret corporate messages that are often complicated, sometimes leading to erroneous decisions from investors (Coyne and Witter, 2002). The interaction between managers and investors has thus to be constructed step by step, in the same way as the interaction between managers and employees, managers and customers, managers and suppliers were already developed, and presumably on the basis of similar modes of organization in order to favour a co-evolution process of collective learning within corporate governance. For instance, characterising the list of key investors, their patterns of behaviour in terms of horizon of analysis (short term, medium term and long term) and dominant content variable (organisation, strategy, finance) can be the first step towards this co-evolution process.

\section{Conclusion}

This paper attempted to reconcile two bodies of analytical and empirical research, namely knowledge governance, on the one hand, and corporate governance, on the other hand. We argued that this reconciliation is fundamental since managers, by defining and selecting innovative processes, and investors, by determining the money that is invested to sustain these

\footnotetext{
${ }^{3}$ For a formalized development of the argument, see Krafft and Ravix (2005).
} 
processes, both take part to the creation and governance of new knowledge by the firm. We showed that this reconciliation can be based on the notion of corporate coherence of the cognitive firm that allows to replace the conventional conflicting vision of corporate governance by a new vision based on cooperation in which managers and investors collectively contribute to corporate development and coherence.

This paper brings thus a new approach on these issues and derives new results. We advocate that the major concern is not to determine the predominance of one actor over the other such as the predominance of the investor over the manager in the shareholder vision or, alternatively, the predominance of the manager over the investor in the critical resource perspective. Contrary to what the corporate governance literature sustains, the actors (the manager and the investor) do not confront in a simultaneous, non-cooperative game; rather they cooperate in a sequential process. The investor must leave the initiative to the manager who makes the entrepreneurial innovative choice. Only in a second step does the investor react to this choice, by comforting or refuting the innovative conjecture.

Corporate governance is thus constructed step by step in a process of collective learning in which each actor embodies a piece of diversified and localised knowledge related to their respective domains and fields of experience, that has to be recombined and used to stimulate corporate development. The manager brings his own competences on the development of learning processes by creating diversity, exploring new opportunities, and providing continuity in innovation. The investor also contributes to the development of learning processes by providing the manager his skills and experience on the financial feasibility of external restructurings (M\&As, cooperations), or internal strategies (compensation plans, reporting activities, information systems). The cooperative interaction of these actors, that we label extended corporate entrepreneurship, is intended to solve collectively the process of coordination and creation of knowledge, and further leads corporate coherence and corporate development.

Since we know today that financial dynamics shapes and is shaped by industrial dynamics, an investigation into the respective functions of corporate finance and managerial control in the creation of new knowledge at the firm level is certainly central to the analysis of complex modes of interactions between finance and industry. However, and quite paradoxically, the issue is not much debated in the literature and the current article provides some key lines for a future agenda of research in the field. 


\section{References}

Aglietta, M., and Rébérioux, A., 2005, Corporate Governance Adrift: a Critique of Shareholder Value, Edward Elgar, Cheltenham.

Anderson, R., Bates, T., Bizjak, J., and Lemmon, M., 2000, "Corporate governance and firm diversification", Financial Management, 29(1), 5-22.

Andrade, G., Mitchell, M. and Stafford, E., 2001, "New evidence and perspectives on mergers", Journal of Economic Perspectives, 15(2), 103-120.

Antonelli, C., 2001, The Microdynamics of Technological Systems, Oxford University Press, Oxford.

Antonelli, C., 2003, The Economics of Innovation, New Technology and Structural Change, Routledge, London.

Antonelli, C., 2006, "The governance of localized knowledge: An Information Economics Approach for the Economics of Knowledge", Industry and Innovation (forthcoming).

Blair, M., 1995, Ownership and Control: Rethinking Corporate Governance for the Twenty First Century, Brookings Institution Press, Washington.

Bresnahan, T., Brynjolfsson, E., and Hitt, L., 2000, "Technology, Organization, and the Demand for Skilled Labor", in M. Blair and T. Kochan (eds.), The new relationship: Human capital in the American corporation, Brookings Institution Press, Washington.

Bresnahan, T., Brynjolfsson, E., and Hitt, L., 2002, "Information Technology, Workplace Organization, and the Demand for Skilled Labor: Firm-Level Evidence", Quarterly Journal of Economics, 117(1), 339-376.

Brown, K., Dittmar, A., Servaes, H., "Corporate Governance, Incentives, and Industry Consolidations", Review of Financial Studies, 18(1), 241-270.

Brynjolfsson, E., Hitt, L., Yang, S., 2002, "Intangible Assets: Computers and Organizational Capital", Brookings Papers on Economic Activity, 0(1), 137-181.

Carpenter, M., Lazonick, W., and O'Sullivan, M., 2003, "The Stock Market and Innovative Capability in the New Economy: The Optical Networking Industry", Industrial and Corporate Change, 12(5), 963-1034.

Chatterjee, S. and Wernerfelt, B., 1991, "The link between resources and type of diversification: theory and evidence", Strategic Management Journal, 12(1), 33-48.

Chesborough, H., 2003, Open innovation: the new imperative for creating and profiting from technology, Harvard Business School Press, Boston.

Coase, R., 1972, "Industrial organisation: a proposal for research", in V. Fuchs (Ed.), Policy issues and research opportunities in industrial organisation, NBER, New York.

Cohen, W., and Levinthal, D., 1990, "Absorptive capacity: a new perspective on learning and innovation", Administrative Science Quarterly, 35(1), 128-152.

Comment, R., and Jarrella, G., 1995, "Corporate focus and stock returns", Journal of Financial Economics, 37(1), 67-87.

Coyne, K., and Witter, J., 2002, "Taking the mystery out of investor behaviour", Harvard Business Review, 80(9), 68-79.

Denis, D., Denis, D., and Sarin, A., 1997, “Agency problems, equity ownership, and corporate diversification", Journal of Finance, 52(1), 135-160.

Donaldson, T., and Preston, L., 1995, "The stakeholder theory of corporation: concepts, evidence and implications", Academy of Management Review, 20(1), 65-91.

Dosi, L., and Malerba, F. (eds), 2002, Special issue: interpreting industrial dynamics 20 years after Nelson and Winter's Evolutionary Theory of Economic Change, Industrial and Corporate Change, 11(4), 3-202. 
Ellig, J., 2002, "Telecommunication mergers and theories of the firm", in Foss, N.J. and Klein, P.G. (eds.) Entrepreneurship and the Firm: Austrian Perspectives on Economic Organization, Cheltenham: Edward Elgar.

Fama, E., 1970, "Efficient capital markets: a review of theory and empirical work", Journal of Finance, 25(2), 383-417.

Foss, N., 1993, "Theories of the firm: competence and strategy perspectives", Journal of Evolutionary Economics, 3(2), 127-144.

Foss, N. and Christensen, J., 2001, "A market process approach to corporate coherence", Managerial and Decision Economics, 22(4-5), 213-226.

Fransman, M., 2002, Telecoms in the Internet Age: From Boom to Burst to..., Oxford University Press, Oxford.

Freeman, C., 1995, "The 'National System of Innovation' in Historical Perspective", Cambridge Journal of Economics, 19(1), 5-24.

Freeman, C., and Louca, F., 2001, As time goes by: From the industrial revolutions to the information revolution, Oxford University Press, Oxford.

Freeman, R., 1984, Strategic Management: a Stakeholder Approach, Pitman Press, Boston.

Gompers, P., and Lerner, J., 1999, The Venture Capital Cycle, MIT Press, Cambridge.

Grenadier, S., and Weiss, A., 1997, "Investment in technological innovations: an option pricing approach", Journal of Financial Economics, 44(3), 397-416.

Griliches, Z., 1980, "R \& D and the Productivity Slowdown", American Economic Review, $70(2), 343-348$.

Grossman, S., and Hart, O., 1986, "The Costs and Benefits of Ownership: A Theory of Vertical and Lateral Integration", Journal of Political Economy, 94(4), 691-719.

Hall, B., 1993, "The Stock Market's Valuation of R\&D Investment during the 1980's", American Economic Review, 83(2), 259-264

Hall, R., 2000, "E-Capital: The Link between the Stock Market and the Labor Market in the 1990s", Brookings Papers on Economic Activity, 0(2), 73-102.

Hall, R., 2001a, "Struggling to Understand the Stock Market", American Economic Review, 9(2), 1-11.

Hall, R., 2001b, “The Stock Market and Capital Accumulation", American Economic Review, 91(5), 1185-1202.

Holmström, B., and Kaplan, S.N., 2001, "Corporate Governance and Merger Activity in the United States: Making sense of the 1980s and 1990s", Journal of Economic Perspectives, 15(2), 121-144.

Jensen, M., 1986, "Agency cost of free cash flow, corporate finance and takeover", American Economic Review, 76(2), 323-329.

Jensen, M., 1993, "'The Modern Industrial Revolution, Exit, and the Failure of Internal Control Systems, Journal of Finance, 48(3), 830-880.

Jorgenson, D., 1995 (Ed.), Productivity, Vol 1 and 2, MIT Press, Cambridge.

Kelly, G., Kelly, D., and Gamble, A. (eds), 1997, Stakeholder Capitalism, Macmillan, Basinsgtoke.

Kirzner, I.M., 1973, Competition and Entrepreneurship, University of Chicago Press, Chicago.

Klein, P.G. and Klein, S.K., 2002, "Do entrepreneurs make predictable mistakes? Evidence from corporate divestitures", in Foss, N.J. and Klein, P.G. (eds.) Entrepreneurship and the Firm: Austrian Perspectives on Economic Organization, Edward Elgar, Cheltenham.

Krafft, J., and Ravix, J.L., 2005, "The governance of innovative firms: an evolutionary perspective", Economics of Innovation and New Technology, 14(3), 125-148.

Lachmann, L.M., 1986, The Market as an Economic Process, Macmillan, London. 
Lang, L., and Stulz, R., 1994, "Tobin's Q, corporate diversification, and firm performance", Journal of Political Economy, 102(6), 1248-1280.

Langlois, R.N. and Robertson, P.L., 1995, Firms, Markets and Economic Change: A Dynamic Theory of Business Institutions, Routledge, London.

Lazonick, W., and O'Sullivan, (eds), 2002, Corporate Governance and Sustainable Prosperity, Palgrave, New York.

Lev, B., and Sougiannis, T., 1996, "The Capitalization, Amortization, and Value-Relevance of R\&D", Journal of Accounting and Economics, 21(1), 107-138.

Loasby, B., 1991, Economics and Evolution, Manchester University Press, Manchester.

Lundvall, B., 1992, National Systems of Innovation: Towards a Theory of Innovation and Interactive Learning, Pinter, London.

Malerba, F., and Orsenigo, L., 1996, "The dynamics of evolution of industry", Industrial and Corporate Change, 5(1), 51-87.

March, J.,1991, "Exploitation and Exploration in Organizational Learning", Organization Science, 2(1), 71-87.

Mayer, D., and Kenney, M., 2004, "Economic Action Does Not Take Place in a Vacuum: Understanding Cisco's Acquisition and Development Strategy", Industry and Innovation, 11, 4, 299-325.

Mazzucato, M., 2002, “The PC Industry: New Economy or Early Life-Cycle?", Review of Economic Dynamics, 5(2), 318-345.

Mazzucato, M., 2003, "Risk, Variety and Volatility: Growth, Innovation and Stock Prices in Early Industry Evolution", Journal of Evolutionary Economics, 13(5), 491-512.

Mazzucato, M., and Semler, W., 1999, "Market Share Instability and Stock Price Volatility during the Industry Life-Cycle: The US Automobile Industry", Journal of Evolutionary Economics, 9(1), 67-96.

Metcalfe, S., 1995, "Technology systems and technology policy in an evolutionary framework", Cambridge Journal of Economics, 19(1), 25-46.

Mitchell, R., Agle, B., Wood, D., 1997, "Toward a theory of stakeholder identification and salience: defining the principle of who and what really counts", Academy of Management Review, 22(4), 853-886.

Nelson, R., 1994, "The Co-evolution of technology, industrial structure, and supporting institutions", Industrial and Corporate Change, 3(1), 47-63.

Nelson, R., and Winter, S., 1982, An Evolutionary Theory of Economic Change, Harvard University Press, Harvard.

Pavitt, K., 2001, "Public policies to support basic research: what can the rest of the world learn from US theory and practice? (and what they should not learn)", Industrial and Corporate Change, 10(3), 761-779.

Penrose, E., 1959, The Theory of the Growth of the Firm, Basil Blackwell, London.

Perez, C., 2002, Technological revolutions and financial capital: the dynamics of bubbles and golden ages, Edward Elgar, Cheltenham.

Piscitello, L., 2004, "Corporate diversification, coherence and economic performance", Industrial and Corporate Change, 13(5), 757-787.

Rajan, R., and Zingales, L., 1998, "Power in a theory of the firm", Quarterly Journal of Economics, 113(2), 387-432.

Ramanujam, V., and Varadarajan, P., 1989, "Research on corporate diversification: a synthesis, Strategic Management Journal, 10(6), 523-551.

Richardson, B.J., 1972, "The organisation of industry", Economic Journal, 82(327), 883-896.

Rumelt, R.P., 1974, Strategy, Structure and Economic Performance, Harvard University Press, Cambridge MA. 
Schleifer, A., and Vishny, R., 1997, "A survey on corporate governance", Journal of Finance, 52(2), 737-783.

Servaes, H., 1996, "The value of diversification during the conglomerate merger wave", Journal of Finance, 51(4), 1201-1225.

Singh, M., Mathur, I., and Gleason, K., 2004, "Governance and performance implications of diversification strategies: evidence from large US firms", The Financial Review, 39(4), 489-526.

Teece, D., and Pisano, G., 1994, "The dynamic capabilities of firms: An introduction", Industrial and Corporate Change, 3(3), 537-556.

Teece, D., Pisano G. and Shuen, A., 1997, "Dynamic capabilities and Strategic Management", Strategic Management Journal, 18(7), 509-533.

Teece, D.J., Rumelt, R., Dosi, G., Winter, S., 1994, "Understanding corporate coherence; theory and evidence", Journal of Economic Behavior and Organization, 23(1), 1-30.

Valliere, D., and Peterson, R., 2004, "Inflating the bubble: examining dot-com investor behaviour", Venture Capital, 6(1), 1-22.

Wheale, P., and Amin, L., 2003, "Bursting the dot.com 'bubble': a case study in investor behaviour", Technology Analysis and Strategic Management, 15(1), 117-136.

Williamson, O., 1985, The Economic Institutions of Capitalism, Free Press, New York.

Witt, U., 2003, The Evolving Economy: Essays on the Evolutionary Approach to Economics, Edward Elgar, Cheltenham

Zingales, L., 1998, "Corporate governance", in P. Newman (Ed.), The New Palgrave Dictionary of Economics and the Law, Stockton Press, London.

Zingales, L., 2000, "In search of new foundations", Journal of Finance, 55(4), 1623-1653. 